\title{
Synthesis, Characterization and Biological Activity of Two New Copper (II) Complexes with N-sulfonamide Ligand
}

\author{
ADRIANA CORINA HANGAN ${ }^{1}$, LAURA GRATIELA VICAS ${ }^{2}$, ROXANA LIANA STAN ${ }^{3 *}$, EMOKE PALL ${ }^{4}$, \\ LUMINITA SIMONA OPREAN ${ }^{1}$, CORINA MARIA LUCIA IONESCU ${ }^{3}$, SANDA ANDREI ${ }^{4}$, \\ ALEXANDRA CRISTINA SEVASTRE BERGHIAN ${ }^{5}$, ELEONORA MARIAN², BOGDAN SEVASTRE ${ }^{4}$ \\ ${ }^{1}$ University of Medicine and Pharmacy luliu Hatieganu Cluj Napoca, Faculty of Pharmacy, Department of Inorganic \\ Chemistry, 8 Victor Babes Str., 400000, Cluj Napoca, Romania \\ 2 University of Oradea, Faculty of Medicine and Pharmacy, Department of Pharmacy, 29 Nicolae Jiga Str., 410610, Oradea, \\ Romania \\ 3University of Medicine and Pharmacy luliu Hatieganu, Faculty of Pharmacy, Department of Pharmaceutical Biochemistry and \\ Clinical Laboratory, 8 Victor Babes Str., 400000, Cluj Napoca, Romania \\ 4University of Agricultural Science and Veterinary Medicine, Faculty of Veterinary Medicine, 3-5 Manastur Str., 400372, Cluj \\ Napoca, Romania
}

\begin{abstract}
Despite the fact that a large number of chemotherapeutic anticancer agents have been discovered, cancer still remains a great cause of deaths worldwide. The purpose of our researches is to discover a new antitumor drug. In this aim, two new $\mathrm{Cu}(\mathrm{II})$ complexes, $\left[\mathrm{Cu}(\mathrm{L})_{2}(\mathrm{py})_{2}\left(\mathrm{H}_{2} \mathrm{O}\right)_{2}\right]\left(\mathrm{C}_{1}\right)$ and $\left[\mathrm{Cu}(\mathrm{L})_{2}(\mathrm{phen})\right]\left(\mathrm{C}_{2}\right)$ with a new ligand, $\mathrm{N}$-(5-trifluoromethyl-[1,3,4]-thiadiazole-2-yi)-benzensulfonamide(HL) were synthesized. The complexes were characterized by elemental analysis, spectral and magnetic determinations. The nuclease activity studies of the complexes confirm their capacity to cleavage the DNA molecule. Both complexes have in vitro antioxidant activity (DPPH, FRAP methods), in vitro (using xanthine/xanthine oxidase system) and in vivo (using S.cerevisiae)SOD mimetic activity. The results of MTT assay on two carcinoma cell lines (HeL a and WM35) indicate that both complexes have antitumor activity, but ( $C_{2}$ ) has a superior activity compared with $\left(\mathrm{C}_{1}\right)$ and with Cisplatin. On normal fibroblast $(\mathrm{HDFa}),\left(\mathrm{C}_{1}\right)$ showed toxicity comparable with Cisplatin, but $\left(\mathrm{C}_{2}\right)$ showed a lower one. Bacterial assays were also performed (by the disk diffusion method) and both complexes have antibacterial activity againstS. aureus, E. coli, P. aeroginosa and B. cereus. All the biological studies are in concordance and show that both complexes have biologic activity but $\left(\mathrm{C}_{2}\right)$ is much more active.
\end{abstract}

Keywords: oxidative DNA cleavage, antioxidant capacity, SOD-mimetic activity, cytotoxicity, antibacterial properties

Metal ions are important for the course of the living organisms' vital functions where they occur under the form of complex or chelated combinations, as well as for the drugs control and analyses [1-4]. Copper exhibits considerable biochemical action either as an essential trace metal or as a constituent of various exogenously administered compounds in humans [5,6].

Current interest in Cu complexes is stemming from their potential use as antimicrobial, antiviral, anti-inflammatory, antitumor agents, enzyme inhibitors, or chemical nuclease [7-11].

The study of N-substituted heterocyclic sulfonamides ligands showed their ability to coordinate biologically important metallic ions. The sulfonamides structures are varied and complex, and offer multiple possibilities to coordinate metallic ions depending on the type of donor atoms in the molecule $(\mathrm{O}, \mathrm{S}, \mathrm{N})$, the stereochemistry of the compounds, the nature of the metallic center that can form complexes, the nature of the anion of the salt that offers the central ion, the synthesis parameters [12].

Copper complexes as artificial nucleases have been shown to possess in vitro anticancer activity and a lower toxicity than platinum drugs. Many of them are active against platinum drug resistant tumor cell lines. In contrast to platinum compounds which covalently bind DNA nucleobases, copper derivatives usually form non-covalent interactions with DNA (intercalation, electrostatic forces of attraction or major/minor groove binding). For the majority of copper complexes reported as DNA cleavage agents, their mode of action is mediated via the formation of ROS generated either by oxidation of $\mathrm{Cu}(\mathrm{II})$ to $\mathrm{Cu}(\mathrm{III})$ or by reduction from $\mathrm{Cu}(\mathrm{II})$ to $\mathrm{Cu}(\mathrm{I})$ in the presence of oxidizing (dihydrogen peroxide or molecular oxygen) or reducing agents (ascorbic acid) [13-15].

The synthesis of $\mathrm{Cu}(\mathrm{II})$ complexes with $\mathrm{N}$-substituted heterocyclic sulfonamides has greatly increased in the past twenty years, due to the diversity of biological activity of the resulting compounds. In this context, for the past several years our group worked on the synthesis of such compounds in order to obtain new antitumor agents and we described the DNA cleavage, SOD-like and antitumor activity of several copper sulphonamide complexes [1621].

In this paper we report the synthesis, the physicochemical characterization of two new $\mathrm{Cu}(\mathrm{II})$ complexes with a N-substituted sulfonamide and we demonstrate their antioxidant, SOD-mimetic, antitumor and antibacterial activities.

\section{Experimental part \\ Materials and physical measurements}

2-amino-5-fluoromethyl-[1,3,4]-thiadiazole, sulfonyl chlorides, pyridine and phenatroline were provided by Aldrich and were used without further purification.

Elemental analyses $(C, N, H, S)$ were performed with Perkin-Elmer elemental analyser. IR spectra were recorded using $\mathrm{KBr}$ disks on a Perkin-Elmer FT-IR 1730 instrument, in the $4000-400 \mathrm{~cm}^{-1}$ range. Electronic paramagnetic spin 
resonance spectrum was performed at room temperature with a Bruker ER 200D instrument. Solid UV-Vis spectra were recorded on a Shimadzu UV-2101 PC spectrophotometer. Mass spectra for the ligand were recorded using the FAB technique, on a VG Autospectrometer. Magetic susceptibility measurements were performed at room temperature according to the Faraday method, using $\mathrm{Hg}\left[\mathrm{Co}(\mathrm{SCN})_{4}\right]$ as standard.

\section{Synthesis}

Synthesis of the ligand $\mathrm{N}$-(5-trifluoromethyl-[1,3,4]thiadiazole-2-yl)-benzensulfonamide ( $\mathrm{HL})\left(\mathrm{C}_{0} \mathrm{H}_{6} \mathrm{~N}_{3} \mathrm{~S}_{2} \mathrm{O}_{2} \mathrm{~F}_{3}\right)$

The ligand was prepared by reacting 2-amino-5trifluoromethyl-[1,3,4]-thiadiazole $(1 \mathrm{mmol})$ with benzenesulfonyl chloride ( $2 \mathrm{mmol}$ ) in a pyridine solution $(6 \mathrm{~mL})$. The mixture was refluxed at $60^{\circ} \mathrm{C}$ for $60 \mathrm{~min} ; 10 \mathrm{~mL}$ of very cold water was then added in the mixture, continuously stirring. The white precipitate formed was filtered and further recrystallized using ethanol.

(HL) $\mathrm{C}_{0} \mathrm{H}_{\mathrm{N}} \mathrm{S}_{2} \mathrm{O}_{2} \mathrm{~F}_{3}(\mathrm{MW}=309)$ :Anal. calcd., \%: C, 34.95; $\mathrm{H}, 1.94 ; \mathrm{N}$, 13.59; S, 20.71. Found, \%: C, 34.89; H, 1.97; N, 13.54; S, 20.67. IR ( $\left.\mathrm{KBr} ; \mathrm{v}, \mathrm{Cm}^{-1}\right)$ : 1550 (thiadiazole), 1341 $(\mathrm{S}=0), 1155(\mathrm{~S}=0) ; 915(\mathrm{~S}-\mathrm{N})$.

The solid electronic spectra show a peak at $322 \mathrm{~nm}$, due to $\pi-\pi^{*}$ transition that appear within the heterocyclic ring. The mass spectra show a molecular peak with a value of 310; the peak is characteristic for the protonated form of the ligand $[\mathrm{HL}-\mathrm{H}]^{+}$.

\section{Synthesis of the complex $\left[\mathrm{Cu}(\mathrm{L})_{2}(\mathrm{py})_{2}\left(\mathrm{H}_{2} \mathrm{O}\right)_{2}\right]\left(\mathrm{C}_{1}\right)$}

A pyridine solution ( $25 \mathrm{~mL}$ pyridine : $\mathrm{H}_{2} \mathrm{O}=2: 3$ ) containing $1 \mathrm{mmol}$ ligand $(\boldsymbol{H L})$ was added to a solution of $\mathrm{CuSO}_{4} \cdot 5 \mathrm{H}_{2} \mathrm{O}\left(4 \mathrm{mmol}^{\mathrm{CuSO}} \mathrm{CH}_{4} \cdot 5 \mathrm{H}_{2} \mathrm{O}\right.$ in $20 \mathrm{~mL}$ pyridine : $\mathrm{H}_{2} \mathrm{O}=1: 1$ ), dropwise and continuously stirring. The resulting dark-blue mixture was stirred for 2 hours at room temperature. Slow evaporation of the solvent during one month allowed the formation of blue crystalline powder.

(C1) C- ${ }_{2} \mathrm{H}_{2} \mathrm{CUN}-\mathrm{S}-\mathrm{O} F(\mathrm{MW}=874)$ : Anal. calcd., \%: C, 39.29; $\mathrm{H}^{28}, 2.58 ; \mathrm{N}^{3}, 12.85 ; \mathrm{S}^{2}, 14.61$. Found, \%: $\mathrm{C}, 39.36 ; \mathrm{H}$, $2.53 ; \mathrm{N}, 12.91 ; \mathrm{S}, 14.53$. IR $\left(\mathrm{KBr} ; \mathrm{v}, \mathrm{Cm}^{-1}\right): 1493$ (thiadiazole); $1322(\mathrm{~S}=0), 1130(\mathrm{~S}=0), 932(\mathrm{~S}-\mathrm{N})$. UVVis (solid; $\lambda, n$ ): $\left.3000^{2 s} \pi \rightarrow \pi^{*}\right), 392$ (LMCT), $590(d-d)$. $\left(\varepsilon=98 \mathrm{~cm}^{-1} M^{-1}\right)^{-1}$. Synthesis of the complex $\left[\mathrm{Cu}(L)_{2}(\right.$ phen $\left.)\right]$ (C)

$1 \mathrm{mmol}$ of ligand $(\boldsymbol{H L})$ was dissolved in $40 \mathrm{~mL}$ of methanol which contained $2 \mathrm{~mL}$ of a $1 \mathrm{M} \mathrm{NaOH}$ solution. Separately, another mixture was prepared by dissolving $0.5 \mathrm{mmol}$ CuSO $5 \mathrm{H}_{2} \mathrm{O}$ and $0.5 \mathrm{mmol}$ of 1,10 phenanthroline (phen) in $25 \mathrm{~mL}$ of methanol. By adding the ligand solution in the $\mathrm{Cu}(\mathrm{II})$-phenanthroline mixture, the color turns to green. After stirring at 35ÚC for an hour, the reaction mixture was filtered in order to remove the precipitate (a complex of copper with phenanthroline). The filtrate was left to stand at room temperature and, after a few days, green crystalline powder was formed.

(C2) $\mathrm{C}-\mathrm{H}_{22} \mathrm{Cu}$ O- $-\mathrm{S}_{4}-\mathrm{O}_{4} \mathrm{~F}_{6}(\mathrm{MW}=1040)$ : Anal. calcd., \%: $\mathrm{C}, 48.46 ; \mathrm{H}^{2}, 2.50 ; \mathrm{N}, 13.46$; S, 12.30. Found, \%: C, 48.12; $\mathrm{H}$, $2.32 ; \mathrm{N}, 13.03 ; \mathrm{S}, 12.53$. IR $\left(\mathrm{KBr} ; v, \mathrm{Cm}^{-1}\right): 1490$ $(v$ (thiadiazole $)) ; 1284\left(v_{\text {asm }}(S=0)\right), 1123\left(v_{\text {sym }}(S=0)\right)$, 938 (í(S-N)).UV/Vis (solidd) $\lambda_{\text {max }} / \mathrm{nm}: 314\left(\pi \stackrel{\text { sym }}{\rightarrow} \pi^{*}\right), 405$ (LMCT), 589 (d-d). 662 (d-d) $\left(\varepsilon=70 \mathrm{~cm}^{-1} \mathrm{M}^{-1}\right)$

\section{Biological assays}

DNA cleavage

Reactions were performed by mixing $7 \mu \mathrm{L}$ of cacodylate buffer $0.1 \mathrm{M}, \mathrm{pH} 6$ (cacodylic acid/sodium cacodylate), $6 \mu \mathrm{L}$ of complex solution (final concentrations: $3,6,9,12$ and $15 \mu \mathrm{M}), 1 \mu \mathrm{L}$ of pUC18DNA solution $(0.25 \mu \mathrm{g} / \mu \mathrm{L}, 750 \mu \mathrm{M}$ in base pairs), and $6 \mu \mathrm{L}$ of activating agent solution $\mathrm{H}_{2} \mathrm{O}_{2}-$ ascorbic acid) in a threefold molar excess relative to the concentration of the complex. The resulting solutions were incubated for $1 \mathrm{~h}$ at $37^{\circ} \mathrm{C}$, after which a quench buffer solution ( $3 \mu \mathrm{L})$ consisting of bromophenol blue $(0.25 \%)$, xylene cyanole $(0.25 \%)$ and glycerol $(30 \%)$ was added. The solution was then subjected to electrophoresis on $0.8 \%$ agarose gel in $0.5 \times$ TBE buffer $(0.045 \mathrm{M}$ Tris, $0.045 \mathrm{M}$ boric acid, and $1 \mathrm{mM}$ EDTA) containing $5 \mu \mathrm{L} / 100 \mathrm{~mL}$ of a solution of ethidium bromide ( $10 \mathrm{mg} / \mathrm{mL}$ ) at $100 \mathrm{~V}$ for $2 \mathrm{~h}$. The bands were photographed on a capturing system (Gelprinter Plus TDI).

To test for the presence of reactive oxygen species (ROS) generated during strand scission and for possible complex-DNA interaction sites, various reactive oxygen intermediate scavengers and groove binders were added to the reaction mixtures. The scavengers used were 2,2,6,6tetramethyl-4-piperidone ( $0.5 \mathrm{M})$, dimethylsulfoxide (DMSO) (14 M), t-butyl alcohol (10.5 M), sodium azide $\left(\mathrm{NaN}_{3}\right)(400 \mathrm{mM})$, superoxide dismutase (SOD) (15 units). In addition, a chelating agent of copper (I), neocuproine $(36 \mu \mathrm{M})$, along with the groove binder distamycin $(80 \mu \mathrm{M})$ were also assayed. Samples were treated as described above $[16,19]$.

\section{In vitro antioxidant activity \\ DPPH radical scavenging assay}

The radical scavenging activity of the $\left(\boldsymbol{C}_{1}\right)$ and $\left(\boldsymbol{C}_{2}\right)$ complexes towards the radical 1,1-diphenyl-2picrylhydrazyl (DPPH) was measured according to Kikuzaki etal. [22]. The sample solution $(50 \mu \mathrm{L}, 20 \mathrm{mg} / \mathrm{mL}$ in DMSO) was mixed thoroughly with a solution of DPPH in methanol ( $1 \mathrm{~mL}, 0.4 \mathrm{mM})$ and brought up with methanol to $5 \mathrm{~mL}$. The mixture was shaken vigorously using a vortex and left to stand for $30 \mathrm{~min}$ at room temperature, in the dark. After that, the absorbance was measured at $517 \mathrm{~nm}$ using a Genesys-10 spectrophotometer. The DPPH solution without sample solution was used as control sample $\left(A_{c}\right)$. The ability to scavenge the DPPH radical was calculated using the following formula:

$$
\% \text { Inhibition }=\left[\left(A_{c}-A_{\text {sample }}\right) / A_{C}\right] \times 100
$$

\section{FRAP method (ferric reducing antioxidant power)}

FRAP method is a simple spectrophotometric method that assesses the antioxidant power of the complexes, being based on the reduction of ferric tripyridyltriazine complex [Fe(III)-TPTZ] by a reductant, at an acid pH. The stock solutions included: $300 \mathrm{mM}$ acetate buffer; $270 \mathrm{mg}$ $\mathrm{FeCl} \cdot 6 \mathrm{H}_{2} \mathrm{O}$ dissolved in $50 \mathrm{~mL}$ distillated water; $150 \mathrm{mg}$ TPTŻ and $150 \mu \mathrm{L} \mathrm{HCl}$, dissolved in $50 \mathrm{~mL}$ distillated water. The working FRAP solution was freshly prepared by mixing $50 \mathrm{~mL}$ acetate buffer, $5 \mathrm{~mL} \mathrm{FeCl} \cdot 6 \mathrm{H}_{2} \mathrm{O}$ solution and $5 \mathrm{~mL}$ TPTZ solution. Trolox was used as a standard solution, the calibration curve was made for concentrations between 0 and $300 \mu \mathrm{M}$, having a correlation coefficient $R^{2}=0.9956$ and the regression equation $(y=0.0017 x+0.0848)$, where $y$ represents absorbance detected at $595 \mathrm{~nm}$. The results are expressed as $\mu \mathrm{mol}$ Trolox equivalents (TE)/100 mLextract $[23,24]$.

\section{In vitro SOD mimetic activity}

The in vitro SOD mimetic activities of the complexes were assayed using the Oberley and Spitz method with some minor modifications [25]. Xanthine $\left(1.5 \times 10^{-4} \mathrm{M}\right)$ and xanthine oxidase in $50 \mathrm{mM}$ potassium phosphate buffer, $p H=7.8$ were used to generate a reproductible and constant flux of superoxide anions. These were detected by the reduction of nitro blue tetrazolium (NBT) $\left(5.6 \times 10^{-5}\right.$ 
M) to blue formazane, which was quantified spectrophotometrically at $560 \mathrm{~nm}$. Solutions of the complexes at different concentrations $(50,25,12.5,2$ and $0.2 \mu \mathrm{M})$ were prepared in $50 \mathrm{mM}$ Tris- $\mathrm{HCl}$ buffer $\mathrm{pH}=7.8$. In each experiment, $0.1 \mathrm{~mL}$ complex solution $+0.1 \mathrm{~mL}$ xanthine oxidase were added to $0.8 \mathrm{~mL}$ of solution containing 0.69 $\mathrm{mL}$ of potassium phosphate buffer $(\mathrm{pH}=7.8), 0.025 \mathrm{~mL}$ of NBT and $0.085 \mathrm{~mL}$ of xanthine. To determine the SOD activities of the complexes, the percentage inhibition of NBT reduction was used. The formation of uric acid from xanthine was followed at $310 \mathrm{~nm}$. The \% inhibition of enzyme activity was substracted from that of NBT. The $I C_{5}$ values (the concentration of complex required to yield $50 \%$ inhibition of NBT reduction) were determined from plots of $\%$ inhibition versus complex concentration. All reagents for these assays were obtained from Sigma and the determinations were performed with a SPECORD 200 PLUS Spectrofotometer.

\section{In vivo SOD mimetic activity}

The protective effect of the complexes $\left(\boldsymbol{C}_{1}\right)$ and $\left(\boldsymbol{C}_{2}\right)$ against free radicals produced by oxidative agents has been determined.

The SOD-like activities of the complexes where evaluated using a strain of S.cerevisiae $\Delta$ sod1 (ATCC96687), which has the ability to delete/insert the SOD gene encoding the synthesis of $\mathrm{Cu}_{2} \mathrm{Zn}, \mathrm{SOD}$. The characteristics of S.cerevisiae $\Delta$ sod1 (ATCC96687) are: MAT aura 3-52 trp1289 his3- $\Delta 1$ leu 2-3 leu 2-112 sod1: URA3). The $\mathrm{Cu}_{2} \mathrm{Zn}, \mathrm{SOD}$ is the main SOD in the cell and it is localizated in the cytoplasm. Yeast cells were grown in YPD reach medium (1\% yeast extract, $2 \%$ peptone and $2 \%$ glycerol). The used culture medium does not contain glucose, it contains glycerol instead, because in its presence the levures can breath. This is determinant, as free radicals are going to be generated during the breath processus taking place in the mithocondria. Solid media contained $1.5 \%$ agar. Cell density from cultures grown overnight was determined by cell counting in a Nebauer hematimetre. $10^{6}$ cells were resuspended in $15 \mathrm{~mL}$ of melted solid YPD media kept at $45^{\circ} \mathrm{C}$. Solutions of the $\left(\boldsymbol{C}_{1}\right)$ and $\left(\boldsymbol{C}_{2}\right)$ complexes in a mixture of DMSO:EtOH (1:4) at increasing concentrations (30, 50, $70 \mu \mathrm{m}$ ) were added to the growth medium. Cell suspensions were poured into Petri dishes and allowed to solidify at room temperature. Paper disks measuring $6 \mathrm{~mm}$ in diameter (Antibiotica test Blättchen) containing $5 \mu \mathrm{L}$ of a 5 $\mathrm{mM}$ menadione solution in ethanol or $5 \mu \mathrm{L}$ of $17.5 \% \mathrm{H}_{2} \mathrm{O}_{2}$ have been used. The diameters of clear zones around the disks, measured after 3 days of incubation at $28^{\circ} \mathrm{C}$, where taken as a quantitative estimate of the protective action [26].

\section{Cell culture}

Three cell lines were used for determining the cytotoxicity of the two copper complexes, a human cervical carcinoma line (HeLa), a human melanoma cell line (WM35) and a human normal fibroblastic epithelial cell line (HDFa) (ATCC Manassas, Virginia, USA). The cell lines were maintained in DMEM (Sigma-Aldrich), supplemented with $10 \%$ fetal bovine serum (Hyclone), 1 mM glutamine (Sigma-Aldrich), $1 \%$ antibiotic/antimycotic 100x (Sigma-Aldrich). The cells were cultured at $37^{\circ} \mathrm{C}$ in an atmosphere of $5 \% \mathrm{CO}_{2}$ and $95 \%$ relative humidity $[18,20,27]$.

\section{Cytotoxicity assays}

For the cell survival the cell lines were plated $\left(1 \times 10^{5}\right.$ cells/ well) in 96 -well plates for $24 \mathrm{~h}$ in normal propagation media. The culture medium was then replaced with complete medium containing two type of complexes $\left(\boldsymbol{C}_{1}\right)$ and $\left(C_{2}\right)$ in 5 different concentrations $(50 \mu \mathrm{M}, 25 \mu \mathrm{M}, 12.5$ $\mu \mathrm{M}, 2 \mu \mathrm{M}$ and $0.2 \mu \mathrm{M})$. The compounds were initially dissolved in DMSO, followed by serial dilutions in media until the final concentration of DMSO was less than $1 \%$. The negative controls were represented by cell lines cultivated in normal expansion medium added with the same amount of diluted DMSO, while the positive control was represented by Cisplatin (Ebewe Pharma Ges.m.b.H. Nfg. KG, Austria) in the same concentration as the complexes. Each experiment was carried out in triplicate. The cellular viability was determined using the MTT assay at 24, 48 and respectively 72 hours. The formazan particles were solubilized with dimethyl sulfoxide (DMSO) (Sigma). The absorbance was read at $550 \mathrm{~nm}$ using a spectrophotometer (Bio-Rad, Hercules, CA, USA). The IC $\mathrm{C}_{50}$ values representing the concentration of complex required to inhibit $50 \%$ of cell proliferation were calculated from the dose-response curves using nonlinear regresion $[18,20,27,28]$.

\section{Antibacterial activity}

Preliminary screening of $\left(\boldsymbol{C}_{1}\right)$ and $\left(\boldsymbol{C}_{2}\right)$ complexes against two Gram-positive bacteria species: $S^{2}$. aureus ATCC 6538P, $B$. cereus ATCC 14579 and against two Gram-negative bacteria species: E. coli ATCC 10536 and P. aeruginosa ATCC 27853 was done using the disk diffusion method [29-32]. As positive control Norfloxacin (Sigma-Aldrich) was used [33]. The reference microbial strains were obtained from American Type Culture Collection (ATCC, Manassas, VA, USA).

The values of the minimum inhibitory concentration were determined using the serial micro-broth dilution method with Müller-Hinton broth, described by Carson et al. [34]. All tests were duplicated and the MIC values were expressed as mean \pm standard deviation.

\section{Statistics}

All the experiments were conducted in triplicates and data are displayed as Mean $\pm S D$, representing the average of independent experiments performed in triplicate. The $I C_{50}$ values representing the complexes concentration required to inhibit $50 \%$ of cell proliferation were calculated from the dose response curve using non-linear regression. Statistical values were generated using GraphPad Prism version 5.0 for Windows, GraphPad Software, San Diego California USA.

\section{Results and discussions}

The chemical structures of the complexes $\left(\boldsymbol{C}_{1}\right),\left(\boldsymbol{C}_{2}\right)$ and of the ligand $(\boldsymbol{H L})$ are given in Figure 1.

\section{The complexes structures}

In complex $\left(\boldsymbol{C}_{1}\right), \mathrm{CuN}_{4} \mathrm{O}_{2}$ chromophore type, the coordination geometry of the $\mathrm{Cu}(\mathrm{II})$ ion is slightly distorted octhaedral. The two deprotonated ligands by $\mathrm{N}_{\text {thiadizzole }}$ atom, two pyridine's molecules as monodentate ligand by $N$ and two water's molecules by $\mathrm{O}_{\text {water }}$ coordinate the metâlicic ion. The structure for the complex ( $\boldsymbol{C}_{2}$ ) shows that the $\mathrm{Cu}(I I)$ ion is four-coordinated and the chromophore type is CuN The $\mathrm{Cu}(\mathrm{II})$ ion is bound symmetrically by two deprotonated ligands and one phenantroline in a square-planar environment $\left(\boldsymbol{C}_{2}\right)$. The sulfonamide ligand $(\boldsymbol{H L})$ coordinates the $\mathrm{Cu}(\mathrm{II})$ ion upon the deprotonation of the $-\mathrm{NH}_{-} \mathrm{SO}_{2}-$ moiety. Each ligand coordinates the metal ion through the one $N_{\text {thiadiazole }}$ atom. The phenantroline's molecules also participate at the $\mathrm{Cu}$ (II) coordination as bidentate ligand by two nitrogen atoms $\mathrm{N}$ 


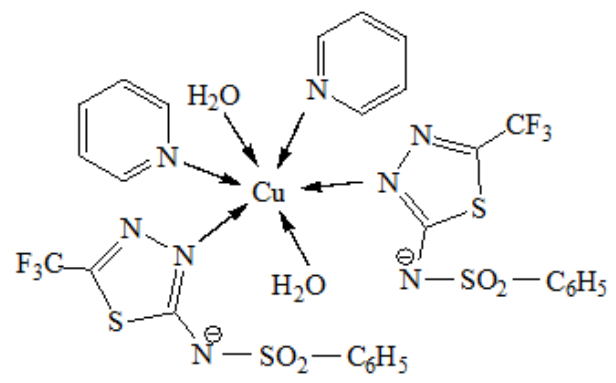

$\left(C_{1}\right)$

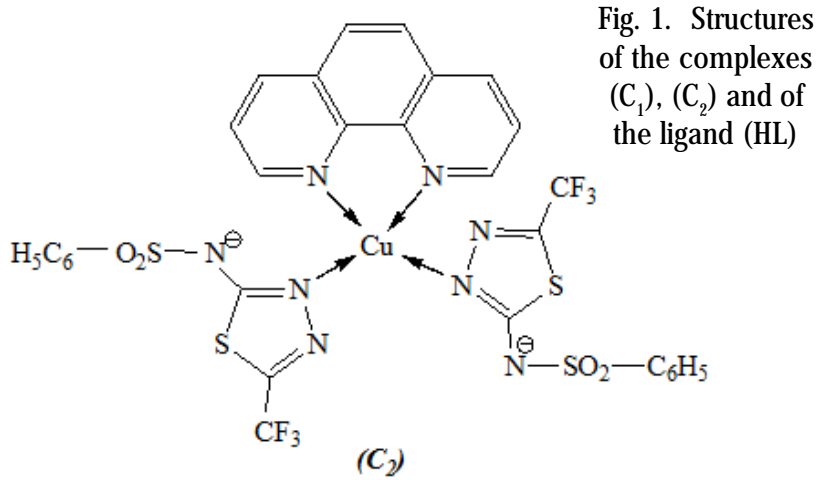<smiles>O=S(=O)(Nc1nnc(C(F)(F)F)s1)c1ccccc1</smiles>

(HL)

\section{Spectroscopic properties}

Comparing the IR spectra of the complexes and of the ligand, the most remarkable modifications appear in the vibrational bands of the thiadiazolic ring, $v(\mathrm{~S}-\mathrm{O})$ and $v$ (S$\mathrm{N}$ ) (in the sulfonamidic group). The band corresponding to the stretching vibrations of the thiadiazolic ring is shifted towards lower frequencies for both complexes: from 1550 $\mathrm{cm}^{-1}$ for ( $H L$ ) to $1493 \mathrm{~cm}^{-1}$ for $\left(C_{1}\right)$ and from $1490 \mathrm{~cm}^{-1}$ for $\left(C_{2}\right)$. The modifications prove the involvement of the thiadiazolic nitrogen in the coordination of the cooper ion; an electronic transfer between the thiadiazolic and sulfonamidic nitrogen atoms may occur upon deprotonation of the sulfonamidic nitrogen $-\mathrm{N}^{(-)}-\mathrm{SO}_{2}$. The bands attributed to $(S=0)$ and $(S=0)$ in the structure of both complexes, are shifted towards lower frequencies $\left(15-20 \mathrm{~cm}^{-1}\right)$; these modifications can be related to the deprotonation of the sulfonamidic nitrogen and subsequent conjugation between the atoms of the group $(\mathrm{N}, \mathrm{S}, \mathrm{O})$. The phenomenon is confirmed by the shifting of the S-N vibrational band toward higher frequencies for both complexes as compared to the ligand $\left(932 \mathrm{~cm}^{-1}\right.$ and 938 $\mathrm{cm}^{-1}$ for the complexes and $915 \mathrm{~cm}^{-1}$ for the ligand). The IR spectra, with all the modifications mentioned above, display a similar pattern to all $\mathrm{Cu}(\mathrm{II})$ complexes described in literature where $\mathrm{N}$-substituted sulfonamides act as ligands. The deprotonation of the sulfonamidic nitrogen, and the coordination of the cooper ion through the nitrogen atoms in the heterocyclic ring are caracteristic for this type of complexes [35].The characteristic bands for the pyridine molecule that coordinates the metal ion cannot be identified due to the superposition of these bands with those of the ligand. The spectrum of the $\left(\boldsymbol{C}_{2}\right)$ complex presents bands at 1125, 1087 and $730 \mathrm{~cm}^{-1}$, which are attributed to the coordinated phenanthroline molecule [36]. In general, the IR spectra are similar to those for the other copper Nsulfonamide compounds [37]. The changes of the IR characteristic bands are mainly due to the sulfonamide deprotonation.
The solid electronic spectra exhibit a maximum at 590 $\mathrm{nm}$, for $\left(\boldsymbol{C}_{\mathbf{1}}\right)$ and at $595 \mathrm{~nm}$, for $\left(\boldsymbol{C}_{2}\right)$, due to $\mathrm{d}$-d transitions; the peaks are characteristic for octahedral distorted and respectively square-planer geometries. The peaks that appear at $392 \mathrm{~nm}$ for $\left(\boldsymbol{C}_{1}\right)$ and at 405 for $\left(\boldsymbol{C}_{2}\right)$ are due to the charge transfer between the ligand and the metal ion $[38,39]$.

\section{EPR and magnetic properties}

The complexes display effective magnetic moments of $1.93 \mathrm{MB}\left(\boldsymbol{C}_{1}\right)$ and $1.83 \mathrm{MB}\left(\boldsymbol{C}_{2}\right)$. This behavior is characteristic for monomers, with no metal-metal interactions $(1.72-2.20 \mathrm{MB})$ and indicates the presence of a single unpaired electron in a $3 \mathrm{~d}$ orbital for the metal ion [39].

The polycrystalline X-band EPR spectrum of the complex $\left(\boldsymbol{C}_{1}\right)$ is axial and for the complex $\left(\boldsymbol{C}_{2}\right)$ is rombic. The parallel region is resolved with hyperfine splitting from cooper. The EPR parameters calculated by simulation are $\mathrm{g} \|=2.26$, $g_{\perp}=2.05$ and $\mathrm{A} \|=154 \times 10^{-4} \mathrm{~cm}^{-1}$ for complex $\left(\boldsymbol{C}_{1}\right)$ and $g_{x}=2.030, g_{x}=2.070, g_{z}=2.140$ and $A||=190 \times 10^{-4} \mathrm{~cm}^{-}$ 1 for complex $\left(\boldsymbol{C}_{2}\right)$ [ 40]. The calculated parameters suggest that the unpaired electron is in a $d_{x 2-y 2}$ or a $d_{x y}$ orbital [41]. According to the Bertini classification, the value of $A$ | [ can be correlated with the geometry of the complex [42].

The structures of the complexes $\left(\boldsymbol{C}_{1}\right)$ and $\left(\boldsymbol{C}_{2}\right)$ resulting from the elemental analysis and the spectral data are shown in Figure 1.

\section{DNA cleavage}

The ability of the complexes to cleave DNA was studied using supercoiled pUC18 DNA in DMF: cacodylate buffer $(0.1 \mathrm{M}, p H 6.0)$ a molar proportion (1:39) in the presence of $\mathrm{H}_{2} \mathrm{O}_{2}$ /ascorbic acid, 3.0-fold excess relative to thecomplex concentration. Control experiments with CuSO were also carried out under the same experimental conditions. The results are presented in Figure 2(a), 2(b).

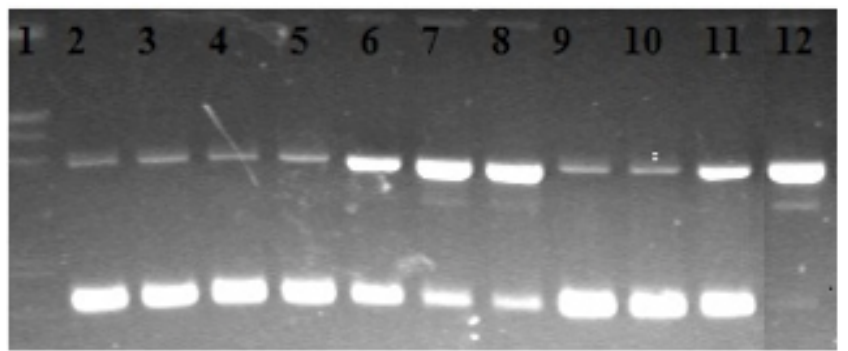

Fig. 2(a). Electroferogram in agarose gel of the pUC18 plasmid treated with the complex $\left(\mathbf{C}_{1}\right)$

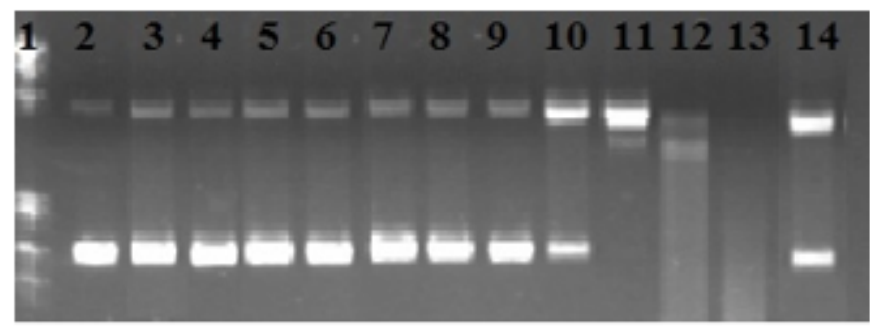

Fig. 2(b). Electroferogram in agarose gel of the pUC18 plasmid treated with the complex $\left(\boldsymbol{C}_{2}\right)$

Complex $\left(\boldsymbol{C}_{1}\right)$ at $18 \mu \mathrm{M}$ (Figure 2(a), lanes 10$)$ produced a partial conversion of closed circular (NC) conformation DNA into its supercoiled form (SC). At $24 \mu \mathrm{M}$, degradation of the supercoiled form to open circular DNA (Figure 2(a), lanes 11) was observed. Under the same conditions, CuSO exhibited less nucleolytic activity than either of the complexes (lanes 4-7). As for the bis(0-phenanthroline) 
copper(II) complex, which is a well-known and very efficient chemical nuclease, we found that at a dose of 24 $\mu \mathrm{M}$, complex $\left(\boldsymbol{C}_{1}\right)$ was less active than $\left[\mathrm{Cu}(\mathrm{phen})_{2}\right]^{2+}$.

It appears that complex $\left(\boldsymbol{C}_{1}\right)$ can destroy DNA in stages, forming the circular form at a concentration of $18 \mu \mathrm{M}$ and then the linear form at a concentration of $24 \mu \mathrm{M}$.At the last concentration, the circular and linear forms coexist (lane 11 ), while at $18 \mu \mathrm{M}$ the circular and the helicoidal form coexist (lane 10). Initially, the cleavage is realized at a single point of the DNA chain, leading to the circular form.A second cleavage then occurs at another point of the chain, leading to the linear form.

For complex $\left(\boldsymbol{C}_{2}\right)$ (Figure 2(b), the DNA cleavage starts at $6 \mu \mathrm{M}$, giving an appreciable amount of plasmid Form II (lane 10). Then, at $9 \mu \mathrm{M}$ the nicked circular and linear forms appear (lane 11). At higher concentrations (lanes 12 and 13), smearing is observed. CuSO ${ }_{4}$ at the highest concentration, $15 \mu \mathrm{M}$, does not induce any DNA cleavage. Overall, the activity of complex $\left(\boldsymbol{C}_{2}\right)$ is higher than that of the bis(o-phenanthroline) copper complex (compare line 11 with line 14). As a consequence, complex $\left(C_{2}\right)$ can be defined as a strong nuclease agent in the presence of $\mathrm{H}_{2} \mathrm{O}_{2} /$ ascorbic acid. When the concentrations of complexes $\left(\boldsymbol{C}_{1}\right)$ and $\left(\boldsymbol{C}_{2}\right)$ are increased whilst keeping those of reducing agents and DNA pUC18 plasmid constant, the amount of SC (Form I) decreases whereas that of NC (Form II) increases. If we compare complex $\left(\boldsymbol{C}_{1}\right)$, containing sulfonamide ligands, with complex $\left(\boldsymbol{C}_{2}^{1}\right)$, which also incorporates 1,10-phen ligand, we can say that the introduction of the phenantroline ligand increases the nuclease activity of the resulting complex.Phenantroline also enhances the activity of the complex for complete destruction of the DNA molecule (smearing).In the presence of an oxidizing agent like hydrogen peroxide, $\mathrm{Cu}(\mathrm{II})$ complexes with phenantroline ligand are known to initiate an oxidative attack on C-1' and C-4' of the 2deoxyribose moiety, leading to the destruction of DNA [43]. The planar aromatic rings of the sulfonamide ligand may allow the complex molecules be intercalated between the DNA base pairs. This would be followed by the destruction of the nucleic acid, caused by the production of ROS in its close vicinity $[44,45]$.

The involvement of ROS in the nuclease mechanism was determined by monitoring the quenching of DNA cleavage in the presence of certain ROS scavengers:DMSO, t-butyl alcohol, sodium azide, 2,2,6,6-tetramethyl-4piperidone, distamycin, superoxide dismutase and neocuproine. We chose a concentration of $24 \mu \mathrm{M}$ for $\left(\boldsymbol{C}_{1}\right)$ and $12 \mu \mathrm{M}$ for $\left(\boldsymbol{C}_{2}\right)$ (in view of the difference in nuclease activity for the two complexes). The assays were performed with $\mathrm{H}_{2} \mathrm{O}_{2}$ /ascorbic acid (in 3.0-fold molar excess relative to the complex concentration) as an activating agent and a concentration 3 times higher for the redox reagents ascorbic acid/ $\mathrm{H}_{2} \mathrm{O}_{2}$. Samples were incubated for one hour, at $37^{\circ} \mathrm{C}$. The resulting electroferograms are presented in Figure 3.

In the presence of both DMSOand of t-butyl alcohol (lanes 4 and 5), we observed a decrease in degradation of the DNA.This can be explained by the presence of $\mathrm{HO}$. radicals in the degradation of DNA, since these inhibitors act by querching these free radicals.

The influence of inhibitors on the nuclease activity of the complexes can be observed in the fact that sodium azide and 2,2,6,6-tetramethyl-4-piperidone(lanes 6 and 7) do not greatly modify the nuclease activity of the complexes.This indicates that singlet oxygen does not participate in the destruction of the DNA.

By adding distamycin(lane 8), the nuclease activity of the complex is slightly increased.This suggests that the activity is not similar to that of distamycin, which is a binder of the minor groove of DNA.

The SOD enzyme leads to a significant increase of the nuclease activity of the complexes (line 9), manifested byan increase of the amount of linear DNA in this experiment (lane 3).SOD catalyzes the dismutation of the superoxide anion radical $\mathrm{O}_{2}$, leading to $\mathrm{H}_{2} \mathrm{O}_{2}$ and $\mathrm{O}_{2}$, which can further produce active species which participate in the destruction of DNA.

In the presence of neocuproine (lane 10), the capacity of the complexes to destroy DNA is much reduced (the helicoidal and circular form coexist). This can be explained by the reduction of the $\mathrm{Cu}(\mathrm{II})$ ion to $\mathrm{Cu}(\mathrm{I})$ as an intermediate step in the DNA degradation process.By adding neocuproine, a stable neocuproine complex of $\mathrm{Cu}(\mathrm{I})$ is formed, thus inhibiting the subsequent reactions required for DNA degradation.

We can conclude that, for these complexes, the destruction of DNA follows a Fenton or Haber-Weiss reaction mechanism [46,47]. A possible pathway for ROS generation would be:

$$
\begin{aligned}
& \mathrm{Cu}(\mathrm{II}) \mathrm{L}+\mathrm{e}^{-} \rightarrow \mathrm{Cu}(\mathrm{I}) \mathrm{L} \\
& \mathrm{Cu}(\mathrm{I}) \mathrm{L}+\mathrm{O}_{-} \rightarrow \mathrm{Cu}(\mathrm{II}) \mathrm{L}+\mathrm{O}_{2}^{\cdot} \\
& 2 \mathrm{O}_{2}^{\circ}+2 \mathrm{H}^{+} \rightarrow \mathrm{O}_{2}+\mathrm{H}_{2} \mathrm{O}_{2} \\
& \mathrm{Cu}(\mathrm{I}) \mathrm{L}+\mathrm{H}_{2} \mathrm{O}_{2} \rightarrow \mathrm{Cu}\left(\mathrm{II}^{\prime} \mathrm{L}^{+}+\mathrm{OH}^{-}+\mathrm{HO} .\right.
\end{aligned}
$$

In vitro antioxidant activity

DPPH-radical scavenging assay

DPPH is a well-know radical which demonstrates a strong absorbtion band centered about $517 \mathrm{~nm}$, and it becomes colorless or pale yellow when it is neutralized. DPPH radical is scavenged by antioxidants through the donation of proton forming the reduced DPPH, and it is commonly used to evaluate the radical scavenging capacity of antioxidants $[48,49]$. The scavenging ability (\%) of the complexes was found $69 \pm 0.23$, for (C1) complexand $80 \pm 0.34$, for (C2) complex. Comparing the scavenging ability, both complexes are less active than ascorbic acid (97.08 \pm 0.52 ) [50] and are more active than some $\mathrm{Cu}$ complexes with flavonoides ligands: $\left[\mathrm{Cu}_{2}\right.$ (quercetin) $\left.\left.\left(\mathrm{H}_{2} \mathrm{O}\right)_{4}\right] \mathrm{Cl}_{2}\right](61.83 \pm 0.14)$ and $\left[\mathrm{Cu}_{3}\right.$ (rutin) $\left.\left(\mathrm{H}_{2} \mathrm{O}\right)_{6} \mathrm{Cl}_{2}\right]=24.70 \pm 0.53$, values taken from literature [51].

\section{FRAP method (ferric reducing antioxidant power)}

The measurement of reducing power defines an important aspect of the antioxidant activity of the complexes. FRAP (mgTE/mL) for ( $\boldsymbol{C}_{1}$ ) complex was found, $80 \pm 0.14$ and for $\left(C_{2}\right)$ complex, $112 \pm 0.14$, results that

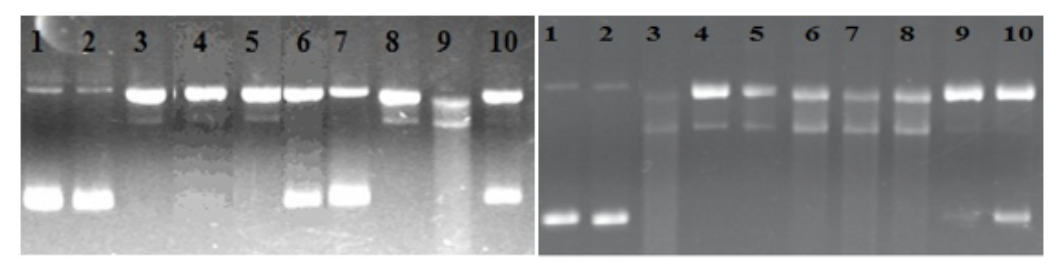

Fig. 3.Electroferogram in agarose gel of the
pUC18 plasmid treated with the $\left(\mathbf{C}_{1}\right)$ and $\left(\mathbf{C}_{2}\right)$
complexes and various inhibiting agents

Complex $\left(C_{1}\right)$ Complex $\left(C_{2}\right)$ 
confirm the superior antioxidant capacity of $\left(\boldsymbol{C}_{2}\right)$ complex, fact demonstrated also by DPPH radical scavenging assay.

\section{In vitro SOD mimetic activity}

The SOD-like activities of $\left(\boldsymbol{C}_{1}\right)$ and $\left(\boldsymbol{C}_{2}\right)$ complexes were tested by an indirect method using the xanthine/xanthine oxidase system as the source of superoxide radicals. Complex $\left(\boldsymbol{C}_{2}\right)$ was more potent than $\left(\boldsymbol{C}_{1}\right)$; the $\mathrm{I} \boldsymbol{C}_{50}$ values were founded $0.115 \mu \mathrm{M}\left(\boldsymbol{C}_{2}\right)$ and $0.223 \mu \mathrm{M}\left(\boldsymbol{C}_{1}\right)$. These values are higher than that for native $\mathrm{Cu}_{2} \mathrm{Zn}, \mathrm{SOD}(0.006 \mu \mathrm{l})$ (that means that the complexes are less active than native SOD) but similar to those of complexes with related sulfonamide ligands $[18,37,52]$.

\section{In vivo SOD mimetic activity}

The in vivo SOD mimetic activity of $\left(\boldsymbol{C}_{1}\right)$ and $\left(\boldsymbol{C}_{2}\right)$ complexes was quantified by a method based on the protection against free radicals provided by the extracts to the yeast $S$. cerevisiae $[23,26,52]$. The SOD-mimetic activity of the complexes on cell growth with a Äsod1 mutant treated with menadione or $\mathrm{H}_{2} \mathrm{O}_{2}$ had been evaluated. The oxidative stress was produced by two oxidative agents: menadione which toxicity is due to the superoxide radical production and $\mathrm{H}_{2} \mathrm{O}_{2}$ which toxicity is registrated due to $\mathrm{HO}$ - radicals.

It was been considered that the complex has a SODmimetic activity if a decrease of the diameter of the inhibition zone is registered versus the control zone. The efficacy was evaluated by comparison of the diameter of the inhibition area for the complex and control (Figure 4).

Complex $\mathrm{Cl}$

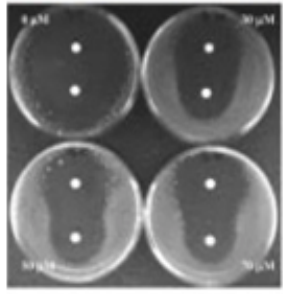

Fig. 4. Effect of $\left(\boldsymbol{C}_{1}\right)$ and $\left(\boldsymbol{C}_{2}\right)$ complexes on the growth of the $\Delta$ sod 1 mutant against free radicals produces by $\mathrm{H}_{2} \mathrm{O}_{2}$ (disk at the top of each Petri disk) and menadione (disk at the bottom of each Petri disk)

In the presence of $\left(\boldsymbol{C}_{1}\right)$ and $\left(\boldsymbol{C}_{2}\right)$ complexes at 30,50 and $70 \mu \mathrm{M}$ a significant reduction of the inhibition area was observed when the oxidative stress is produced by both menadione and $\mathrm{H}_{2} \mathrm{O}_{2}$ The diameter of the inhibition area for both complexes in different concentrations, using menadione and $\mathrm{H}_{2} \mathrm{O}_{2}$ are given in Table 1.

The reduction of the inhibition area is between $25-30 \%$ for the complex $\left(\boldsymbol{C}_{1}\right)$ and $41.25-45 \%$ for the complex $\left(\boldsymbol{C}_{2}\right)$ against oxidative stress generated by menadione. The protective activities of the complexes do not seem to be dependent by increasing the complexes concentration.
The protection of the complexes against free radicals generated by $\mathrm{H}_{2} \mathrm{O}_{2}$ is lower than in the case of free radicals generated by menadione. $\left(\boldsymbol{C}_{1}\right)$ complex produce a reduction of the inhibition diameter about $18.75-23.75 \%$ while $\left(\boldsymbol{C}_{2}\right)$ complex between $30-33.75 \%$. Nor in this case the protective action produced by the complexes does not depend on complexes concentration.

Both complexes are able to protect efficiently against superoxide anions, but $\left(\boldsymbol{C}_{2}\right)$ complex register a higher SODmimetic activity compared with $\left(\boldsymbol{C}_{1}\right)$ complex. They could be considered as promising effective agents against toxicity of superoxide anion, improving significantly the growth of Âsodl strain. They supply the $\mathrm{Cu}_{2} \mathrm{Zn}, \mathrm{SOD}$ deficiency of the mutant. These levels of protection are superior to those obtained for other complexes of $\mathrm{Cu}$ (II) with sulfonamide ligand cited in the literature $[22,53,54]$. For this reason both complexes are potential therapeutic agents in the prevention and treatment of diseases mediated by free radicals.

\section{Cytotoxicities of the complexes}

$\left(\boldsymbol{C}_{1}\right)$ and $\left(\boldsymbol{C}_{2}\right)$ complexes were examined for their antiproliferative properties. The in vitro cytotoxicity of $\left(\boldsymbol{C}_{1}\right)$ and $\left(\boldsymbol{C}_{2}\right)$ copper complexes were tested on two human carcinoma cells, a cervical line (HeLa) and a melanoma cell line (WM35); as well as on human normal fibroblastic epithelial cell line (HDFa), using Cisplatin as positive control. The response was quantified using 3-(4,5-dimethyl-2thioazolyl)-2,5-diphenyl tetrazolium bromide (MTT) colorimetric assay. The cells were exposed to various concentrations of each complex (ranging between 0.2 and $50 \mu \mathrm{M})$ at 24,48 and 72 hours.

The results revealed a promising profile, the complexes expressing different levels of cytotoxicity. On both tumor cell lines: HeLa and WM35, complex ( $\left.\boldsymbol{C}_{2}\right)$ was more potent as compared to $\left(\boldsymbol{C}_{1}\right)$ and more potent than Cisplatin, the ${ } C_{50}$ values being lower than those of Cisplatin. $\left(C_{1}\right)$ complex evoked also cytotoxicity, but a weaker one. No significant differences were found between $I C_{50}$ values obtained for the two complexes at 24,48 and $72^{50}$ hours (Table 2).

The presence of phenanthroline in $\left(\boldsymbol{C}_{2}\right)$ complex clearly increases the activity of the compound toward DNA cleavage. Due to the greater hydrophobic character of phenanthroline, the binding of $\left(\boldsymbol{C}_{2}\right)$ complex to DNA is expected to be stabilized through greater hydrophobic interactions, which may contribute to its higher toxicity [18].

On human normal fibroblast (HDFa line), ( $C_{\text {, }}$ )complex showed a toxicity comparable with Cisplatin, but $\left(\boldsymbol{C}_{2}\right)$ complex showed a lower toxicity than Cisplatin (Table 2).

In this study we demonstrated that $\left(\boldsymbol{C}_{2}\right)$ complex has a superior antitumor activity on both HeLa and WM35 human cell lines comparative with Cisplatin. In addition complex $\left(C_{2}\right)$ is less toxic on human HDFa cells compared to Cisplatin.

\begin{tabular}{|c|c|c|c|c|}
\hline $\begin{array}{c}\text { Complex } \\
(\mu \mathrm{M})\end{array}$ & \multicolumn{2}{|c|}{$\begin{array}{c}\text { Complex }\left(\mathrm{C}_{1}\right) \\
\text { Diameter of the inhibition area }(\mathrm{cm})\end{array}$} & $\begin{array}{c}\text { Complex }\left(\mathrm{C}_{2}\right) \\
\text { Diameter of the inhibition } \\
\text { area }(\mathrm{cm})\end{array}$ \\
\cline { 2 - 5 } & Menadione & $\mathrm{H}_{2} \mathrm{O}_{2}$ & Menadione & $\mathrm{H}_{2} \mathrm{O}_{2}$ \\
\hline $\begin{array}{c}\text { Control } \\
\text { Menadione 5 mM; } \\
\left.\mathrm{H}_{2} \mathrm{O}_{2} 17.5 \%\right)\end{array}$ & 8 & 7.5 & 8 & 7.5 \\
\hline 30 & 6 & & & \\
\hline 50 & 5.6 & 6.5 & 4.7 & 5.6 \\
\hline 70 & 5.6 & 6.3 & 4.5 & 5.4 \\
\hline
\end{tabular}

Table 1

THE DIAMETER OF INHIBITION AREA FOR $\left(\boldsymbol{C}_{1}\right)$ and $\left(\boldsymbol{C}_{2}\right)$ COMPLEXES, IN DIFFERENT CONCENTRATIONS, USING MENADIONE AND $\mathrm{H}_{2} \mathrm{O}_{2}$ 


\begin{tabular}{|c|c|c|c|c|}
\hline \multirow[t]{2}{*}{ Cells } & \multirow[t]{2}{*}{ Complex } & \multicolumn{3}{|c|}{ IC50 $(\mu M)$} \\
\hline & & $24 \mathrm{~h}$ & $48 \mathrm{~h}$ & $72 \mathrm{~h}$ \\
\hline HeLa cells & (CII) & $9.33 \pm 0.18$ & $6.08 \pm 0.13$ & $4.28 \pm 0.06$ \\
\hline & $\left(C_{2}\right)$ & $4.21 \pm 0.16$ & $2.36 \pm 0.07$ & $1.08 \pm 0.02$ \\
\hline & Cisplatin & $20.04 \pm 0.05$ & $5.97 \pm 0.11$ & $2.60=0.08$ \\
\hline WM35 cells & $\left(C_{I}\right)^{-}$ & $14.00 \pm 0.12$ & $11.81 \pm 0.05$ & $6.80=0.22$ \\
\hline & (C) & $9.52 \pm 0.17$ & $2.45 \pm 0.07$ & $0.34 \pm 0.05$ \\
\hline & Cisplatin & $27.07 \pm 1.00$ & $10.12 \pm 0.03$ & $5.55 \pm 0.07$ \\
\hline HDFa cells & $\left(C_{1}\right)$ & $13.81=0.34$ & $4.00 \pm 0.02$ & $1.12 \pm 0.03$ \\
\hline & $\left(C_{2}\right)$ & $34.23 \pm 1.02$ & $18.62 \pm 0.43$ & $10.15 \pm 0.09$ \\
\hline & Cisplatin & $13.46 \pm 1.04$ & $3.45 \pm 0.13$ & $1.21 \pm 0.07$ \\
\hline
\end{tabular}

Table 2

$I_{50}$ VALUES OF THE COMPLEX $\left(\boldsymbol{C}_{1}\right)$, COMPLEX $\left(\boldsymbol{C}_{2}\right)$ AND CISPLATIN ON HUMAN CERVICAL CARCINOMA LINE (HeLa), HUMAN MELANOMA CELL LINE (WM35) AND ON HUMAN NORMAL FIBROBLASTIC EPITHELIAL

CELL LINE (HDFa) (VERSUS UNTREATED CELLS)

$(M E A N \pm S D)(n=3)$

\begin{tabular}{|c|c|c|c|c|}
\hline \multirow[t]{2}{*}{ Complex } & \multicolumn{4}{|c|}{$\mathrm{MIC}(\mathrm{mg} / \mathrm{mL})$} \\
\hline & S. aureus & B. cereus & E. coli & P. aeroginosa \\
\hline$\left(C_{l}\right)$ & 2.6 & 1.5 & 2.6 & 2.6 \\
\hline$\left(C_{2}\right)$ & $2.6^{-}$ & $1.5^{-}$ & 2.6 & $2.6^{-}$ \\
\hline Norfloxacin & 2 & 2 & 2 & 2 \\
\hline
\end{tabular}

Table 3 MIC DETERMINATION RESULTS OF COMPLEXES $\left(\boldsymbol{C}_{1}\right)$ AND $\left(\boldsymbol{C}_{2}\right)$ AGAINST BACTERIAL STRAINS

Antibacterial activity

Both $\left(\boldsymbol{C}_{1}\right)$ and $\left(\boldsymbol{C}_{2}\right)$ complexes were found active against the four microorganisms, the MIC values are given in Table 3.

The results reveal that both complexes have similar antibacterial activity against $S$ aureus, $E$. coli and $P$. aeroginosa, but less than Norfloxacin. Against $B$. cereus both complexes have shown a better antibacterial activity and superior to Norfloxacin activity.

The antibacterial activity may be due to the following mechanisms: inhibition of ribonucleoside diphosphate reductase enzyme which helps in DNA synthesis; by oxidative rupture, creation of lesions in DNA strand or by binding to the nitrogen base of DNA or RNA results in inhibit base replication [55].

\section{Conclusions}

Two new Copper (II) complexes with N-substituted sulfonamide were synthesized. The molecular structures for the complexes were attributed using the data obtained from elemental analysis, spectral (IR, UV-Vis, EPR) and magnetic determinations. The complexes have a superior nuclease activity as compared to the non-coordinated $\mathrm{Cu}(\mathrm{II})$ ion. The use of scavengers of ROS indicates that the hydroxyl and the superoxide anions are the main radicals that break the DNA strands. Both complexes have antioxidant, SOD mimetic and antibacterial activities. The cytotoxicity of the complexes on HeLa and WM35 carcinoma cell lines indicate that both complexes have antitumor activity but $\left(\boldsymbol{C}_{2}\right)$ is much more active, even more active than Cisplatin. On human normal fibroblast (HDFa line), ( $\left.\boldsymbol{C}_{1}\right)$ complex showed a toxicity comparable with Cisplatin, but $\left(\boldsymbol{C}_{2}\right)$ complex showed a lower one.All the biological studies are in concordance and show that both complexes have biologic activity but $\left(\boldsymbol{C}_{2}\right)$ is much more potent. Because the results are promising, in the future we propose to perform in vivo studies for $\left(\boldsymbol{C}_{2}\right)$ complex.

Acknowledgement:This research was funded by the Ministry of Research and Innovation through Program 1 - Development of the National Research and Development System, Subprogram 1.2 Institutional Performance - Projects for Financing the Excellence in CDI, Contract no. 37PFE/06.11.2018 as part of the project Increasing the institutional performance through consolidation and development of research directions within the USAMVCN.

\section{References}

1.RUSU, D.,STANILA, A., MARIAN, I.O., MARIAN, C.O., RUSU, M., LUCACIU, R.,Rev. Chim.(Bucharest), 60, no. 9, 2009, p. 939.
2.ARSENE, A.L., UIVAROSI, V., MITREA, N.,FEBS J ., 277, no.1, 2010, p. 239.

3.GROZAV, A., PORUMB, I.D., GAINA, L.I., FILIP, L., HANGANU, D., Molecules, 260, no. 22, 2017, p. 1.

4.J URCA, T., MARIAN, E., VICA', L.G., MURE'AN, M.E., FRITEA, L. Metal complexes of pharmaceutical sciences. Spectroscopic Analyses Developments and Applications, IntechOpen, Edited by Eram Charmin, 2017, 7, p. 1167.

5.IAKOVIDIS, I., DELIMARIS, I., PIPERAKIS, S.M., Mol. Biol. Int., 2011, p. 13.

6.DANIEL, K.G., GUPTA, P, HARBACH, R.H., GUIDA, W.C., DOU, Q.P., Biochem. Pharmacol., 67,no. 6, 2004, p. 1139.

7.WEDER, J.E., DILLON, C.T., HAMBLEY, T.W., KENNEDY, B.J ., LAY, P.A., BIFFIN, J.R., REGTOP, H.L., DAVIES, N.M., Coord. Chem. Rev., 232, no. 1-2, 2002, p. 95.

8.HANGAN A, BORODI G, FILIP X, TRIPON C, MORARI C, OPREAN L, FILIP C., Acta Crystallogr. B, 66, no. 6, 2010, p. 615.

9.TISATO, F., MARZANO, C., PORCHIA, M., PELLEI, M., SANTINI, C.,Med.Res. Rev., 30, no.4, 2010, p. 708.

10.TRIPATHI, L., KUMAR, P., SINGHAI, A.K.,Indian J. Cancer, 44, no. 2, 2007, p. 62.

11.HORDYJ EWSKA, A., POPIOLEK, L., KOCOT, J. Biometals, 27, no. 4, 2014, p. 611.

12.HANGAN, A., BODOKI, A., OPREAN, L., CRI'AN, O., MIHALCA, I., Farmacia, 60, no. 6, 2012, p. 932.

13.HORN, D., BARRIENTOS, A., IUBMB LIFE, 60, no. 7, 2008, p. 421. 14.MONDOLA, P., DAMIANO, S., SASSO, A., SANTILLO, M., Front. Physiol., 7, 2016, p. 594.

15.J OMOVA, K., VALKO, M., Toxicology, 283, no. 2-3, 2011, p. 65. 16.HANGAN, A.C., TURZA, A., STAN, R.L., STEFAN, R., OPREAN, L.S., Russ. J. Coord. Chem., 41, no. 6, 2015, p. 395.

17.HANGAN, A.C., TURZA, A., STAN, R.L., SEVASTRE, B., PALL, E., CETEAN, S., OPREAN, L.S., J. Chem. SCi., 128, no. 5, 2016, p. 815.

18.HANGAN, A.C., STAN, R.L., TURZA, A., OPREAN, L.S., PALL, E., GHEORGHE-CETEAN, S., SEVASTRE, B., Transit. Met. Chem., 42, no. 2, 2017, p. 153.

19.HANGAN, A.C., STAN, R.L., SEVASTRE, B., GHEORGHE-CETEAN, S., OPREAN, L., Farmacia, 65, no. 3, 2017, p. 368.

20.HANGAN, A.C., BORODI, G., STAN, R.L., PALL, E., CENARIU, M., OPREAN, L.S., SEVASTRE, B., Inorg. Chim. Acta, 482, 2018, p. 884.

21.HANGAN, A.C., TURZA, A., STAN, R.L., OPREAN, L.S., Rev. Chim.(Bucharest), 69, no. 6, 2018, p. 1407.

22.KIKUZAKI, H., HISAMOTO, M., HIROSE, K., AKIYAMA, K., TANIGUCHI, H., J.Agric. Food Chem., 2002, 50, no. 7, p. 2161.

23.MARIAN, E., VICAS, L.G., JURCA, T., MURESAN, M., STAN, R.L., SEVASTRE, B., DIACONEASA, Z., IONESCU, C., HANGAN, A.C., Farmacia, 65, no. 6, 2017, p. 940.

24.OLAH, N.K., HANGANU, D., OPREAN, R., JPC, 17, no. 1, 2004, p. 18. 
25.OBERLAY, L.W., SPOTZ, D.R. Handbook of methods for oxygen radical research. CRC Press. Boca Raton. FL: RA Greenwald, 1986, p. 217-220.

26.MARIAN, E., VICA', L.G., JURCA, T., MURE'AN, M., PALLAG, A.; STAN, R.L.; SEVASTRE, B.; DIACONEASA, Z., IONESCU, C., HANGAN, A.C., Rev. Chim.(Bucharest), 69, no. 2, 2018, p. 365.

27.SEVASTRE, B., SARPATAKI, O., STAN, R.L., TAULESCU, M., SEVASTREBERGHIAN, A.C., OLAH, N.K.,FURTUNA, F., HANGANU, D., HANGAN, A.C.,CENARIU, M., BALDEA, l., Farmacia, 65, no. 1, 2017, p. 56.

28.SEVASTRE, B., SARPATAKI, O., OLAH, N.K., STAN, R.L., TAULESCU, M., MAECUS, I., CATOI, C., Farmacia, 62, no. 5, 2014, p. 907.

29.MARIAN, E., MURE'AN, M., JURCA, T., VICAS, L., Farmacia, 61 , no. 3, 2013, p. 518-524.

30.BENEDEC, D., HANGANU, D., ONIGA, I., FILIP, L., BISCHIN, C., SILAGHI-DUMITRESCU, R., TIPERCIUC, B., VLASE, L., Molecules, 21 no. 8, 2016, p. 1050.

31.BAUER, A.W., KIRBY, W.M.M., SHERRIS, J.C., TURCK, M., Am. J. Clin. Path., 45, no. 4, 1966, p. 493.

32.SINGH, D.P., MALIK, V., KUMAR, K., SHARMA, C., ANEJA, K.R., Spectrochim. Acta A, 76, no. 1,2010, p. 45.

33.ANDREWS, J.M., JAC, 48, 2001, 48, p. 16

34.CARSON, C.F., HAMMER, K.A., RILEY, T.V., Microbios, 82, no.332, 1995, p. 181.

35.GONZALEZ-ALVAREZ, M., ALZUET, G., BORRAS, J., DEL CASTILLOAGUDO, L., MONTEJ O-BERNARDO, J.M.; GARCIA-GRANDA, S., J Inorg. Biochem., 98, no. 2, 2004, p. 189.

36.INSKEEP, R.G., J. Inorg. Nucl. Chem., 24, no. 7, 1962, p. 763.

37.GONZALEZ-ALVAREZ, M., ALZUET, G., BORRAS, J., DEL CASTILLOAGUDO, L., MONTEJ O-BERNARDO, J.M., GARCIA-GRANDA, S.,J. Biol. Inorg. Chem., 8, no. 1-2, 2003, p. 112.

38.LEVER, ABP. Inorganic electronic spectroscopy: Studies in physical an theoretical chemistry, Elsevier, New York, 1984.

39.BELOSO, I., BORRAS, J., CASTRO, J., GARCIA-VAZQUEZ, J.A., PEREZLOURIDO, P., ROMERO, J., SOUSA, A., Eur. J. Inorg. Chem., 3, 2004, p. 635.

40.WINEPR-Simfonia 1.25. Karlsruhe: Bruker Analytik GmbH, 19941996.
41.GONZALEZ-ALAVAREZ, M., ALZUET, G., BORRAS, J., MARCIAS, M., M. DEL OLMO, M., LIU-GONZALEZ, M., SANZ, F., J. Inorg. Biochem., 89, 2002, p. 29.

42.BERTINI, I., DRAGO, R. ESR and NMR of paramagnetic species in biological and related systems. Dordrecht: Springer. D Reidel Publishing Company, 1980.

43.SIGMAN, D.S., CHEN, C.B., Annu. Rev. Biochem., 59, 1990, p. 207. 44.MARCIAS, B., GARCIA, I., VILLA, M.V., BORRAS, J., GONZALEZALVAREZ, M., CASTINEIRAS, J. Inorg. Biochem., 96, no. 2-3, 2003, p. 367.

45.LI, L., KARLIN, K.D., ROKITA, S.E., J. Am. Chem. Soc., 127, no. 2, 2005, p. 520.

46.HABER, F., WEISS, J., Proc. Soc. Lond. A, 147, no. 861, 1934, p. 332351.

47.DETMER, C.A., PAMATONG, F.V., BOCARSLY, J.R., Inorg. Chem., 35, no. 21, 1996, p. 629.

48.IELCIU, I., HANGANU, D., PALTINEAN, R., VLASE, L., FREDERICH, M., GHELDIU, A.M., BENEDEC, D., CRISAN, G., Pak. J. Pharm. Sci., 31,no. 2, 2018, p. 677.

49.STAN, R.L., SEVASTRE, B., HANGAN, A.C., BOTA, S., HANGANU, D., IONESCU, C.M.L., POPOVICI, C., SEVASTRE-BERGHIAN, A.C., DREANCA, A., VICAS, L.G., Rev. Chim.(Bucharest)), 70, no. 6, 2019,p. 1893.

50.DRAGOSTIN, O.A., LUPASCU, F., VASILE, C., MARES, M., NASTASA, V., MORARU, R.F., PIEPTU, D., PORFIRE, L., Molecules, 18, no. 4, 2013, 18, p. 4140.

51.DE SOUZA, R.F.V., DE GIOVANI, W.F., Redox report,9, no. 1, 2004, p. 97.

52.CASANOVA, J., ALZUET, G., BORRAS, J., LATTORE, J., SANAU, M., GARCIA-GRANDA, S., J. Inorg. Biochem., 60, no. 3, 1995, p. 219.

53.STAROSTA, R.; STOKOWA, K., FLOREK, M., KROL, J., CHWILKOW SKA, A., KULBACKA, J., SACZKO, J., SKALA, J., JEZOW SKA-BOJ CZUK, M., J. Inorg. Biochem.,105, no. 8, 2011, p. 1102.

54.RAMAKRISHNAN, S., SHAKTHIPRIYA, D., SURESH, E., PERIASAMY, V.S., AKBARSHA, M.A., PALANIAN, M., Inorg. Chem., 50, no. 14, 2011, p. 6458.

55.SABIR, A., VANDNA, S., PREETI, J., VISHWAS, T.,J . Saudi Chem. Soc., 23, no. 1, 2019, p. 52.

Manuscript received: 14.05 .2019 